Meta

Journal des traducteurs

Translators' Journal

\title{
"As any Jock knows..."
}

\section{Mary Coppin}

Volume 27, numéro 2, juin 1982

URI : https://id.erudit.org/iderudit/002368ar

DOI : https://doi.org/10.7202/002368ar

Aller au sommaire du numéro

Éditeur(s)

Les Presses de l'Université de Montréal

ISSN

0026-0452 (imprimé)

1492-1421 (numérique)

Découvrir la revue

Citer cet article

Coppin, M. (1982). "As any Jock knows...". Meta, 27(2), 211-214.

https://doi.org/10.7202/002368ar

Ce document est protégé par la loi sur le droit d'auteur. L’utilisation des services d'Érudit (y compris la reproduction) est assujettie à sa politique d'utilisation que vous pouvez consulter en ligne.

https://apropos.erudit.org/fr/usagers/politique-dutilisation/
Cet article est diffusé et préservé par Érudit.

Érudit est un consortium interuniversitaire sans but lucratif composé de l’Université de Montréal, l'Université Laval et l'Université du Québec à Montréal. Il a pour mission la promotion et la valorisation de la recherche. https://www.erudit.org/fr/ 


\section{"AS ANY JOCK KNOWS..."”}

In a recent issue of Maclean's magazine, in an article on satiric stand up comic, turned producer David Steinberg, who is slight of build and of modest height, the writer states: "On the raquetball court he's regarded as a bit of a terror", and quotes Steinberg as saying 'I'm surprising - I play a lot of sports. I'm not expected to be a jock" '!

Such a reference to himself would leave us slightly bewildered if we had recourse only to the 1971 edition of the Webster International Dictionary, which tells us that "jock" is a nickname for Jack, a country boy, a soldier in a Scottish regiment, a jockey, a disc jockey or a jockstrap ${ }^{2}$. It would also impel any terminologist to delve deeper for a satisfactory explanation.

6. Le cahier $\mathrm{n}^{\circ} 4$ de Néologie en marche publié en 1976 par l'Office de la langue française propose une demi-douzaine d'autres équivalents.

1. Maclean's, Toronto, Maclean Hunter Ltd., Weekly, October 12, 1981, p. 24.

2. Webster's Third New International Dictionary, (1971), Springfield, G \& C Merriam Company, at term. 
Considering the possible meanings for jock and still relying on the Webster International, we find the following entry: "Jockstrap, also jock or jockey strap... A supporter for the genitals worn by men participating in sports or strenuous activities: an athletic supporter" ${ }^{3}$. Athletic supporter is not defined under its own heading but the term itself begs consideration of athletic support, support and supporter; and the semantic elements of supporter lead us to suspensor, suspensory and suspensorium. We thus have 10 terms to consider whose synonymic values are in question. The Webster definition quoted above is a fertile field for study.

Jockstrap, jock and jockey strap are indicated as synonymous, but the use of jock out of context is certainly ill-advised because of its numerous other meanings. Jockey strap is a longer version of jockstrap and might be less usable for that reason. The use of the indefinite article "an" in referring to the athletic supporter is significant, implying a generic rather than a specific value, that is, that a jockstrap is but one of various supporters. Athletic support is merely a briefed down version of the longer term, but support and supporter warrant analysis.

Support is defined as "the act, process or operation of supporting, or the condition of being supported" ". Obviously, in this sense, support is in the abstract and would have little meaning in our present study, unless it were used in context. A supporter, according to Webster, is "a woven or knitted band or an elastic device for supporting a part (a wrist supporter)" 5 . The Random House definition is very similar except that it gives jockstrap as an example ${ }^{6}$. Supporter then, in this sense, is a generic term.

The Webster definition of supporter goes one step further and shows suspensory as a synonym of athletic supporter. A suspensory is "something that suspends or holds up - specifically a band or pouch for supporting a part (as the scrotum)" 7 . There is no indication as to subject field. However, the Oxford English Dictionary classifies suspensory as surgical and anatomical, defines it as "a suspensory bandage, ligament, etc" ; ... having the function of suspending, i.e. of supporting something suspended" and lists suspensor and suspensorium as synonyms ${ }^{8}$. These terms certainly share semantic elements with the jockstrap and the athletic supporter families, but their target public appears to be different and there is no evidence of their use in the sports equipment subject field. We will therefore not consider them further in this study.

Further analysis of the definition of jockstrap in the Webster International reveals that jockstrap, jock and jockey strap are classified as slang ${ }^{9}$. This in a dictionary which is chary of usage labels. The slang epithet is based on the fact

\footnotetext{
3. Id ibid, at term.

4. Id ibid, at term.

5. Id ibid, at term.

6. Random House Dictionary of the English Language (1966), New York, Random House Inc., at term.

7. Webster's Third New International Dictionary, op. cit., at term.

8. The Shorter Oxford English Dictionary, (1950), Oxford, Clarendon Press, Vol. 2, at term.

9. Webster's Third New International Dictionary, op. cit., at term.
} 
that jock refers to the penis. Conversely, Random House, which is respected for its usage labels, does not denote jockstrap as slang ${ }^{10}$. But this is by no means the most fascinating aspect of this analysis.

If we move forward to the 1979 edition of the Webster Collegiate Dictionary, we find that jockey strap has been dropped and jockstrap, still indicated as slang, is no longer defined ${ }^{11}$. It bears a cross-reference to athletic supporter which now includes the precise definition associated in the 1971 Webster International with jockstrap, to wit "a supporter for the genitals worn by men participating in sports or strenuous activities" 12 . Curiously enough, it bears no cross-reference to jockstrap. This reflects an evolution wherein jockstrap has been relegated to a secondary, if not a minor, position and athletic supporter is shown as the main term to describe the concept. This is all the more surprising because during the same chronological period four letter and other explicit terminology has become more acceptable.

In the same 1979 edition jock is cross-referenced to jockstrap and athletic supporter and is now also indicated as "an athlete - especially a college athlete" ${ }^{13}$. This explains David Steinberg's reference to himself! Random House, in its much earlier dictionary, provides a similar entry but classifies it as slang ${ }^{14}$.

The Oxford Dictionary, it must be said, is eloquent in its silence on jockstrap and athletic supporter although one would think that British athletes, especially soccer players, would wear such an article.

From a usage point of view, in the spoken word, because of its connotation, no English lady or gentleman of tender sensibilities would use jockstrap in polite conversation to refer to an athletic supporter. On the other hand, when discussing this project with several young physical education graduates, it was suggested that the term was athletic support rather than athletic supporter. Further findings lent credence to this suggestion.

Jockstrap belongs in the category of "locker room" language. In that connection, although several attempts to visit the locker room of the Montreal Forum for an "on site" inspection were rebuffed, in spite of the avowed serious nature of the research, it was possible to examine the product (furtively) at several stores. Manufacturers refer to athletic supporter and athletic support. And advertisement in the Athletic Journal has an overall lead in of "Bike (the manufacturer) Supports the Nation" and displays its products: "Mens' Varsity supporter, jogging nylon supporter, youth supporter, youth soft supporter" ${ }^{15}$. A

10. Random House Dictionary of the English Language, op. cit., at term. Plaice, Mary, "A Few Notes on English Dictionaries etc." in Le Furet, Bulletin de documentation de la Société des traducteurs du Québec, Montréal, Société des traducteurs du Québec, 1978, Vol. 2, $\mathrm{n}^{\circ} 1$, p. 3 .

11. Webster's New Collegiate Dictionary (1979): Toronto, Thomas Allen \& Son Ltd., at term.

12. Id ibid, at term.

13. Id ibid, at term.

14. Random House Dictionary of the English Language, op. cit., at term.

15. Athletic Journal, Evanston, Illinois, Athletic Journal Publishing Company, Monthly, 1980, Vol. $60, \mathrm{n}^{\circ} 5$, p. $40,41$. 
sports catalogue with detailed illustrations shows "Pro sport athletic supporters - Superlite protective cups for use with pouch supporters" 16 . The Canadian Tire Catalogue ${ }^{17}$ also features supports and supporters as in the following illustration:

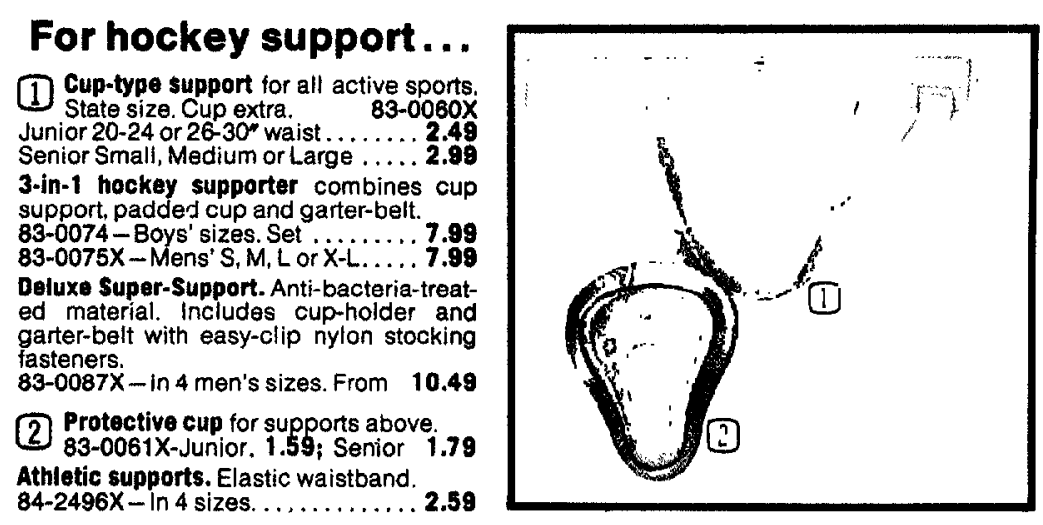

It can be seen from this that both manufacturers and advertisers use the abstract support and the generic supporter freely but this is acceptable because the product itself or the illustration eliminates any confusion as to their meaning. It is significant to note, however, the frequent use of the abbreviated term athletic support. It is also worth emphasizing that nowhere in the material reviewed was there any reference to jock or jockstrap, in spite of the fact that the information was directed primarily towards a male readership.

Jockstrap and athletic supporter are synonymous but should be used synonymously with caution. Jockstrap should be relegated to the vernacular for those who indulge in such language. Jockey strap appears to be obsolete. Jock cannot be used out of context because, in addition to its other meanings, it is now a vogue word to denote a macho male image. The abstract support and the generic supporter create no problem when the illustration or the context clearly indicates that they refer to the athletic supporter. Athletic supporter is acceptable English to describe the concept under study and close on its heels is athletic support to reflect the identical concept in an abbreviated form.

MARY COPPIN

16. Sports Catalogue, Toronto, Jack Watson Sports Inc. 1972-73, p. 42.

17. Canadian Tire Catalogue, Toronto, Canadian Tire Corporation Ltd., Winter 1981-82, p. 219. 